\title{
Modification of natural sorbent for providing it with bactericidal and bacteriostatic properties
}

\author{
Irina Martemianova ${ }^{1,{ }^{*}}$, Luiza Nadeina ${ }^{1}$, Evgenii Plotnikov $^{1}$, Dmitrii Martemianov ${ }^{1}$ \\ ${ }^{1}$ Tomsk Polytechnic University, Lenin av. 30, Tomsk, 634050, Russia
}

\begin{abstract}
Currently, the problem of water purification from chemical and microbiological contaminations is very important. Sorption technologies are one of the effective and easy-to-use water purification techniques. To prevent the growth of microbiological contaminations on the surface of investigated sorbents, the surface of the investigated sorbents was treated by aqueous solution of copper sulphate with the further study of bactericidal and bacteriostatic activity. The results of sorption efficiency of original and modified zeolite samples of Kholinsk deposit are presented in this paper. These results were obtained, when $\mathrm{Zn}^{2+}$ and $\mathrm{Pb}^{2+}$ ions were removed from the simulated solutions. It was concluded that it is possible to provide natural zeolites with bactericidal and bacteriostatic properties.
\end{abstract}

\section{Introduction}

One of the current problems is to provide people with clean drinking water. Natural mineral sorbents are often used in water purification due to their low cost and higher sorption capacity. The review of periodic printed publications has shown that sorption processes have not been studied well yet. They need to be studied in more detail. Zeolite is one of well-known natural minerals possessing good sorption properties. According to these properties, zeolites are used to purify industrial wastewater from heavy metals such as lead, zinc, copper, nickel, cadmium, chromium, and others. Microbiological pollution is known to appear on the surface of sorbent in the water purification module. It is necessary to provide sorption materials (zeolites) with bacteriostatic properties in order to prevent the growth of microbiological pollution on their surface. In order not to reproduce microbes in the filtered water, sorption material needs to be provided with bactericidal properties.

Copper is known to possess a number of useful properties. It prevents bacteria, harmful fungi and other organisms to produce on the different surfaces. It has been proved that copper is required for eubolism. It has anti-inflammatory, antiulcer, anticonvulsive, and anticarcinogenic effect. Copper oxygenates cells, and it participates in energy metabolism. It has a good effect on skin. Copper benefits when vascular malformations and diabetes

* Corresponding author: martemiv@yandex.ru 
mellitus. But there is a basic requirement. The thing is, the copper content in water should not exceed maximum permissible concentration (MPC).

The aim of this investigation is to immobilize copper salts on the surface and inside natural zeolite pores of Kholinsk deposit (the Republic of Buryatia, Russia) in order to provide them with bactericidal and bacteriostatic properties. Physico-chemical investigations should be carried out according to original and modified samples of natural sorbents (zeolites). Sorption properties of investigated materials should be identified in removing $\mathrm{Zn}^{2+}$ and $\mathrm{Pb}^{2+}$ ions from the simulated solutions.

\section{Materials and methods}

The natural zeolites samples of Kholinsk deposit were modified with copper sulphate water solution $\left(\mathrm{CuSO}_{4} * 5 \mathrm{H}_{2} \mathrm{O}\right)$. These samples were the subject of investigation in the paper. To obtain required fractions, zeolite of Kholinsk deposit was crushed in the agata mortar. After that it was sifted using the sieves with $0.1 \mathrm{~mm}, 0.5 \mathrm{~mm}$ and $1 \mathrm{~mm}$ mesh sizes. As a result of sifting the fractions of zeolites with the sizes less than $0.1 \mathrm{~mm}$ and $0.5-1 \mathrm{~mm}$ were selected.

The modification of zeolite samples was carried out under 3 different conditions:

Modification 1. Three grams of zeolite sample were kept in $100 \mathrm{~cm}^{3}$ of the copper sulphate water solution with $5 \mathrm{~g} / \mathrm{dm}^{3}$ concentration for 24 hours. It was mixed intermittently. Then the solution poured out, and the sample was dried for 6 hours at the temperature of $120{ }^{\circ} \mathrm{C}$;

Modification 2. Three grams of zeolite sample were kept in $100 \mathrm{~cm}^{3}$ of the copper sulphate water solution with $10 \mathrm{~g} / \mathrm{dm}^{3}$ concentration for 24 hours. It was mixed intermittently. Then the solution poured out, and the sample was dried for 6 hours at the temperature of $120{ }^{\circ} \mathrm{C}$;

Modification 3. Three grams of zeolite sample were kept in $200 \mathrm{~cm}^{3}$ of the copper sulphate water solution with $10 \mathrm{~g} / \mathrm{dm}^{3}$ concentration for 24 hours. It was intermittently mixed. Then the solution poured out, and the sample was dried for 6 hours at the temperature of $120{ }^{\circ} \mathrm{C}$.

Eight different zeolite samples of Kholinsk deposit were used to carry out the investigations: 1). \# 1. The fraction size of sample was less than $0,1 \mathrm{~mm} ; 2$ ). \# 2. The fraction size of sample was less than $0,1 \mathrm{~mm}$. Modification 1; 3). \# 3. The fraction size of sample was less than $0,1 \mathrm{~mm}$. Modification $2 ; 4)$. \# 4 . The fraction size of sample was less than $0,1 \mathrm{~mm}$. Modification 3; 5). \# 5. The fraction size of sample was less than 0,5-1 mm; 6). \# 6. The fraction size of sample was less than 0,5-1 mm. Modification 1; 7). \# 7. The fraction size of sample was less than 0,5-1 mm. Modification 2; 8). \# 8. The fraction size of sample was less than 0,5-1 mm. Modification 3.

The method of thermal nitrogen desorption was used to determine specific surface and specific pore volume of the original and modified samples. The analyzer "SORBTOMETR M" (LLC "Katakon", Russia) was used.

The sorption of $\mathrm{Zn}^{2+}, \mathrm{Pb}^{2+}$ ions from the simulated solutions was carried out under static condition with the use of investigated zeolite samples. These samples contained different quantity of copper on their surface and inside pores. The weight of zeolite samples was 0.2 g. They were poured with $20 \mathrm{~cm}^{3}$ of the simulated solution containing $\mathrm{Zn}^{2+}$ or $\mathrm{Pb}^{2+}$ ions. The initial concentration of $\mathrm{Zn}^{2+}$ ions in the solution was $5.16 \mathrm{mg} / \mathrm{dm}^{3}$. The initial concentration of $\mathrm{Pb}^{2+}$ ions in the simulated solution was equal to $5.03 \mathrm{mg} / \mathrm{dm}^{3}$. The simulated solutions were prepared with the use of bidistilled water as well as state standard samples of the composition of zinc and lead ions. The sorption carried out in stirring with a magnetic stirrer. The contact time was different: 1; 5; 15; 30 and 60 minutes. After stirring, 
the solutions were separated from the sorbent by filtration with a help of "Blue ribbon" paper filter. Then the equilibrium concentrations of $\mathrm{Zn}^{2+}, \mathrm{Pb}^{2+}$ ions were defined by the method of inversion voltamperometry with a help of the analyzer TA-07 (LLC "Technoanalit", Russia).

The determination of the copper washing out from the investigated zeolite samples was carried out under static condition, with the use of bidistilled water, and under the conditions described above $\left(0.2 \mathrm{~g}\right.$ of sample per $100 \mathrm{~cm}^{3}$ of bidistilled water).

Bacteriostatic properties of original and modified zeolite samples of Kholinsk deposit were defined in the following way. The culture of Escherichia coli (concentration: $2 \times 10^{7}$ $\mathrm{CFU} / \mathrm{cm}^{3}$ and volume $-0.1 \mathrm{~cm}^{3}$ ) was placed on Petri dish containing a standard medium (meat infusion agar). Then, Escherichia coli was distributed with a glass spreading rod on the surface of Petri dish. Medium on Petri dish was divided into halves. $0.1 \mathrm{~g}$ of the investigated zeolite sample was put on one half. After that, Petri dish was shut, and placed in the thermostat at a temperature of $37^{\circ} \mathrm{C}$. Petri dish was placed in the thermostat for a day. After that, the culture growth in the zone of application of the sample, and in the checking half were compared.

\section{Results}

Physical-chemical parameters of Kholinsk's zeolite samples such as granulometric composition, specific surface and specific pore volume are presented in Table 1.

Table 1. Physical-chemical parameters of zeolites of Kholinsk deposit and their modified analogues.

\begin{tabular}{cccc}
\hline $\begin{array}{c}\text { Zeoli } \\
\text { te sample }\end{array}$ & $\begin{array}{c}\text { Particle size, } \\
\mathrm{mm}\end{array}$ & Specific surface, $\mathrm{m}^{2} / \mathrm{g}$ & $\begin{array}{c}\text { Specific pore volume, } \\
\mathrm{cm}^{3} / \mathrm{g}\end{array}$ \\
\hline$\# 1$ & & 22.4 & 0.009 \\
$\# 2$ & less than 0.1 & 19.7 & 0.008 \\
$\# 3$ & 19.1 & 0.008 \\
$\# 4$ & 18.7 & 0.008 \\
$\# 5$ & 27.65 & 0.012 \\
$\# 6$ & 25.2 & 0.011 \\
$\# 7$ & & 25.1 & 0.011 \\
$\# 8$ & $0.5-1$ & 21.5 & 0.009 \\
\hline
\end{tabular}

As Table 1 shows, zeolite samples settled in the strong concentration solutions have a decrease of specific surface and specific pore volume. This can be explained in a certain way: $\mathrm{Cu}^{2+} \quad$ ions penetrate into the branched porous structure of zeolites, and they are kept there (mechanical adsorption), and thereby their presence decreases the internal pore volume. The decrease of specific surface is carried out by the same principle. The internal surface is covered with $\mathrm{Cu}^{2+}$ ions, and they reduce the internal surface.

Degree of $\mathrm{Cu}^{2+}$ ions washing out from the modified zeolite samples according to different contact time of the sample with bidistilled water is presented in Fig.1. The study of $\mathrm{Cu}^{2+}$ ion washing out in water was carried out with the use of only modified zeolite 
samples. This is due to the fact that there is practically no $\mathrm{Cu}^{2+}$ ions washing out in water in the initial samples (non-modified samples).

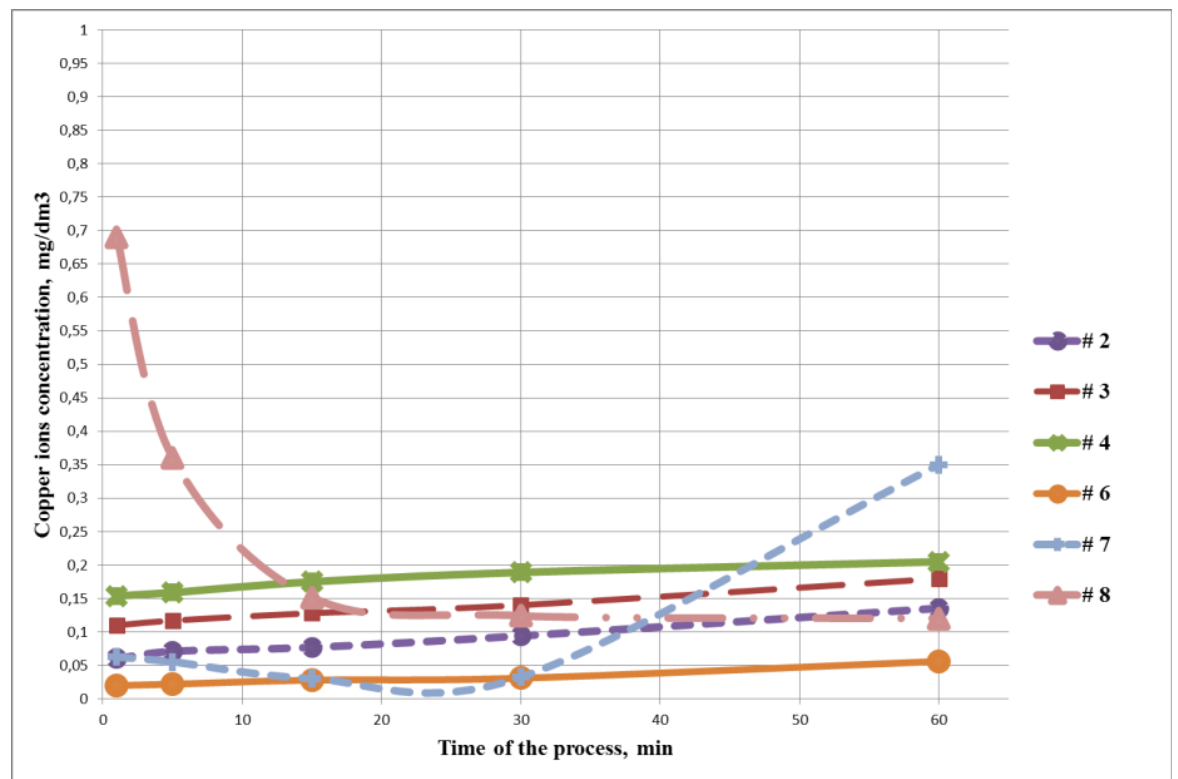

Fig. 1. Degree of $\mathrm{Cu}^{2+}$ ions washing out from the investigated samples in bidistilled water.

Figure 1 shows that the degree of $\mathrm{Cu}^{2+}$ ion washing out in water in all modified zeolite samples is within the range of maximum permissible concentration in drinking water (MPC in drinking water (Russia) $-1 \mathrm{mg} / \mathrm{dm}^{3}$ ).

Sorption characteristics of the investigated zeolite samples of Kholinsk deposit in removing of $\mathrm{Zn}^{2+}$ ions from the simulated solutions are presented in Figure 2. Sorption was carried out under static condition in stirring.

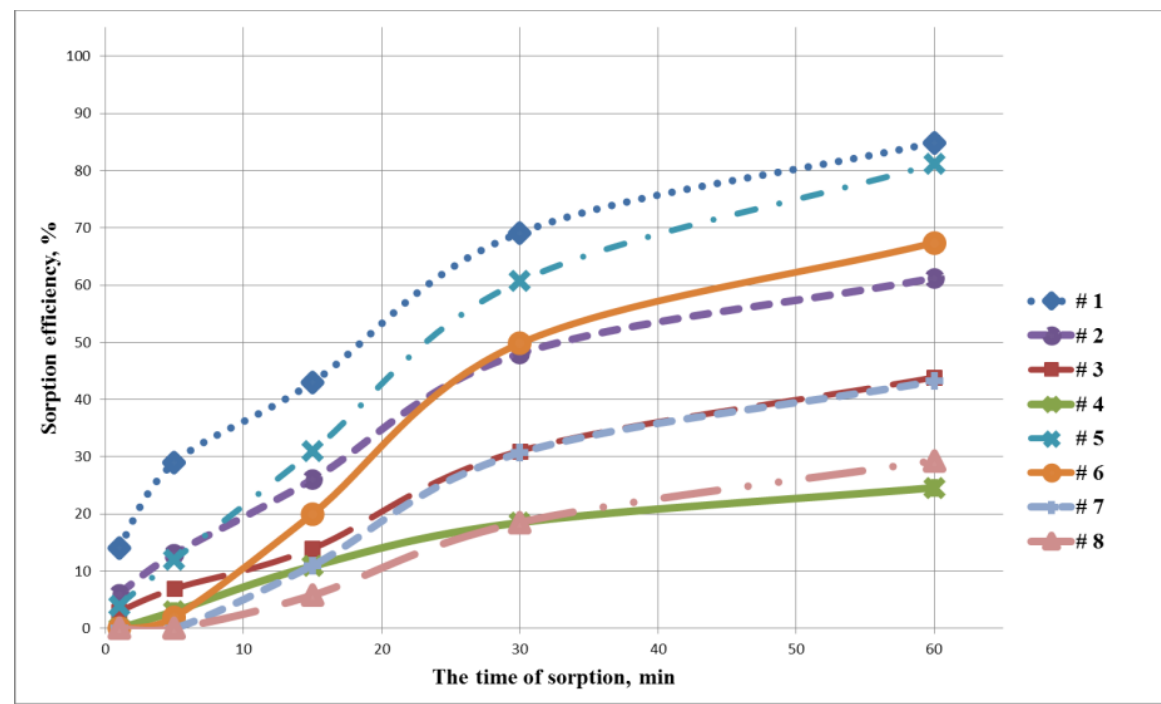

Fig. 2. Sorption capacity of investigated zeolite samples in removing of $\mathrm{Zn}^{2+}$ ions from the simulated solution. 
As shown (Figure 2), the best sorption properties revealed for the intact (not modified) zeolite samples. Opposite, the modified zeolite samples (with high content in the structure of $\mathrm{Cu}^{2+}$ ions) showed the lowest sorption characteristics.

Sorption properties of investigated zeolite samples while extracting of $\mathrm{Pb}^{2+}$ ions from the simulated solution under static condition are given in Figure 3.

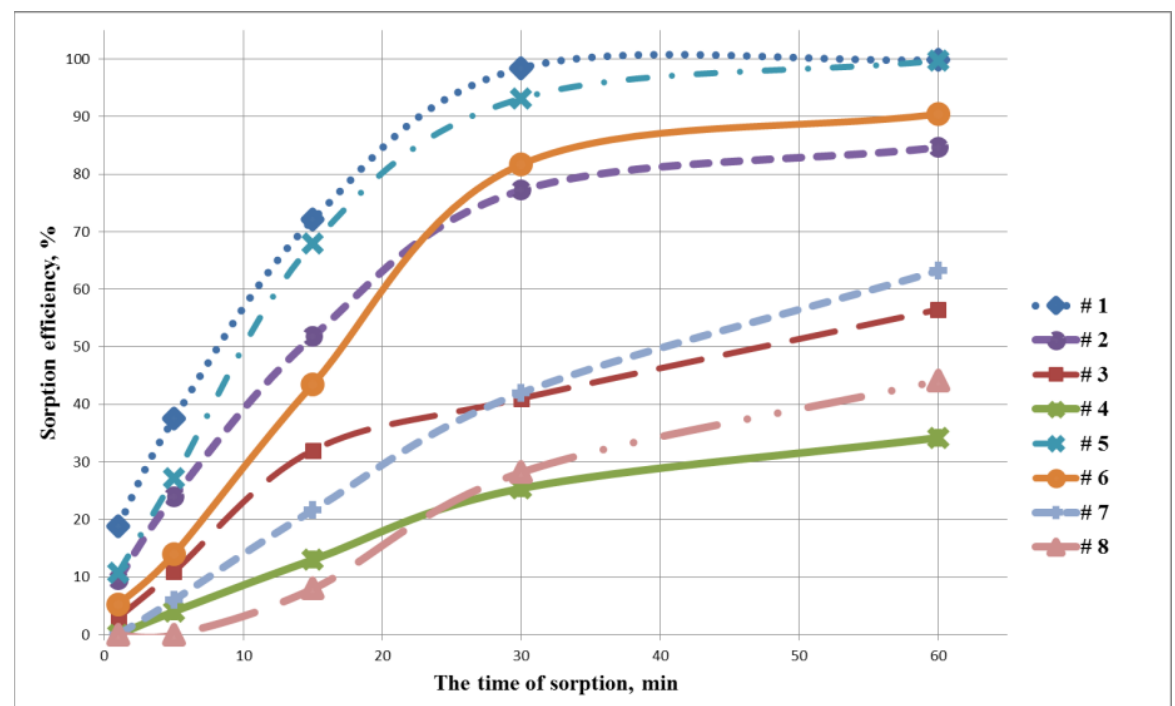

Fig. 3. Sorption capacity of investigated zeolite samples while extracting of $\mathrm{Pb}^{2+}$ ions from the simulated solution.

Figure 3 shows that intact (not modified) zeolite sample revealed the best sorption properties for removing $\mathrm{Pb} 2+$ ions from the model solution. The modified zeolite samples possessed lower sorption properties which gradually decrease with increasing content of $\mathrm{Cu}^{2+}$ ions in the structure of the zeolite. Modified samples with a particle size less than 0.1 $\mathrm{mm}$ showed better sorption properties at short contact time, but worse ones during prolonged sorption process. Bactericidal and bacteriostatic characteristics of investigated zeolite samples in the process of influece on the culture of Escherichia coli are presented in Table 2 .

Table 2. Determination of bactericidal and bacteriostatic properties of original and modified zeolite samples of Kholinsk deposit.

\begin{tabular}{|c|c|c|c|}
\hline Zeolite sample & $\begin{array}{l}\text { Particl } \\
\text { e size, } \\
\text { mm }\end{array}$ & $\begin{array}{l}\text { Concentration of } \\
\text { Escherichia coli, } \\
\text { CFU/ml }\end{array}$ & $\begin{array}{l}\text { Inhibition of Escherichia } \\
\text { coli growth (radius), mm }\end{array}$ \\
\hline $\begin{array}{l}\text { Petri dish with } \\
\text { Escherichia coli } \\
\text { (check) }\end{array}$ & & & Confluent growth \\
\hline \# 1 & & & Confluent growth \\
\hline$\# 2$ & less than & & Confluent growth \\
\hline \#3 & 0.1 & & 5 \\
\hline$\# 4$ & & $2 * 10^{7}$ & 8 \\
\hline
\end{tabular}




$\begin{array}{lcc}\text { \# } 5 & \text { Confluent growth } \\ \text { \# } 6 & \text { Confluent growth } \\ \text { \# } 7 & 0.5-1.0 & 2 \\ \text { \# } 8 & & 4\end{array}$

As Table 2 shows, confluent growth of Escherichia coli is observed on Petri dish (check sample) in twenty-four hours of settling in the thermostat. The different fractions of the original zeolite samples (\# 1 and \# 5), and the samples \# 2 and \# 6 modified by the solution, containing the least content of copper sulphate, have the same result. Some bactericidal and bacteriostatic effects can be observed in samples \# 3 and \# 7. The growth inhibition of Escherichia coli is observed in a radius of $5 \mathrm{~mm}$ (fraction less than $0.1 \mathrm{~mm}$ ) and $2 \mathrm{~mm}$ (fraction $0.5-1 \mathrm{~mm}$ ) appropriately round the zeolite sample. Zeolite samples \# 4 and \# 8 show better bacteriostatic and bactericidal properties.

This is due to the fact that more $\mathrm{Cu}^{2+}$ ions wash out from the porous structure of zeolites. Modified zeolite samples with lesser fractional composition have better bactericidal and bacteriostatic properties.

As the investigation indicates, in providing zeolite samples with bactericidal and bacteriostatic properties, the successful result can be observed only in samples \# 3, \# 7 (modification 2), and samples \# 4, \# 8 (modification 3).

The modified zeolite samples \# 2, \# 6 (modification 1) do not produce bactericidal and bacteriostatic effect, and that is why they also don't correspond with the aim of the study. Zeolite samples \# 3 and \# 7 (modification 2) are optimal, because they have the capacity to remove efficiently $\mathrm{Zn}^{2+}$ and $\mathrm{Pb}^{2+}$ ions from the simulated solutions, and they have bactericidal and bacteriostatic properties.

\section{Conclusion}

1. The natural zeolite samples of Kholinsk deposit modified by $\mathrm{Cu}^{2+}$ ions were obtained.

2. Specific surface and specific pore volume of investigated samples were identified.

3. The degrees of $\mathrm{Cu}^{2+}$ ions washing out from presented natural zeolite samples of Kholinsk deposit were investigated before and after modification.

4. Sorption were carried out with the use of investigated samples under static conditions in removing $\mathrm{Zn}^{2+}$ and $\mathrm{Pb}^{2+}$ ions from the simulated solutions.

5. Bacteriostatic characteristics of the investigated zeolite samples in the process of Escherichia coli growth inhibition were identified.

6. The most optimal modified zeolite samples with bactericidal and bacteriostatic properties, and sorption activity to $\mathrm{Zn}^{2+}$ and $\mathrm{Pb}^{2+}$ ions have been identified (samples \#3 and \#7).

This study was supported with the grant of the President of the Russian Federation to support of young Russian scientists MK-5939.2016.8

\section{References}

1. Frog B, Levchenko A 1996 Water treatment (MSU, Moscow)

2. Telitchenko M, Ostroumov S. 1990 Introduction to Problems of Biochemical Ecology: Biotechnology, agriculture, protection of the environment (Moscow: Science).

3. Kosoy V, Bazhenov A 2001 Water and Ecology: Problems and Solutions (Rus) 1: 4045 
4. Plotnikov E, Martemianova I, Martemianov D, et al 2015 Procedia Chemistry 15: 219 $-224$

5. Baidina N 1994 Soil science. 9:121 - 125

6. Martemianov D, Galanov A, Yurmazova T et al 2014 Proceedings of the higher educational institutions. Chemistry and chemical technology. 57:30-33

7. Martemianov D, Galanov A, Yurmazova T 2013 Basic Research. 8: 666-670

8. Martemianov D, Korotkova E, Galanov A 2012 Bulletin of the Karaganda University. 3: 61-65. 